\title{
Partindo de um museu: uma introdução à história social da psicologia
}

\section{Starting from a museum: an introduction to the social history of Psychology}

\section{A partir de un museo: una introducción a la historia social de la psicología}

\section{Sérgio Cirino*}

Universidade Federal de Minas Gerais - UFMG, Belo Horizonte, Minas Gerais, Brasil

\section{Deborah Christina Lopes Hoffmam**}

Pontifícia Universidade Católica de Minas Gerais - PUC-MG, Betim, Minas Gerais, Brasil

Portugal, F., Facchinetti, C., \& Castro, A. (Orgs.) (2018). História Social da Psicologia. Rio de J aneiro: Nau.

Diante da pergunta "por que devemos estudar história", imaginemos a seguinte resposta: "para nos divertirmos!" Essa foi a maneira bemhumorada encontrada pelo pensador francês Marc Bloch, na primeira metade do séc. XX, para tratar de um tema tão sério e importante a história. Fazendo referência a Marc Bloch e a essa forma leve e descontraída de sua abordagem, Francisco Portugal, Cristiana Facchinetti e Alexandre Castro organizaram o livro "História Social da Psicologia". Defendendo o argumento de que por trás de uma história existe sempre outra história, os organizadores admitem que o que vem antes afeta diretamente a maneira pela qual o conhecimento será construído. Assim, além de atender à demanda de um projeto financiado pelo CNPq, que previa a elaboração de um livro, a obra reúne reflexões que problematizam tanto a produção quanto as condições de produção da história da Psicologia.

As reflexões iniciais partem da ideia de que, de maneira geral, os estudantes costumam se posicionar frente ao conhecimento histórico como se estivessem realizando uma visita a um museu clássico: caminham por entre as galerias, observam as produções e vão absorvendo as informações de maneira passiva, sem problematizar os motivos que levaram àquela organização específica das obras. Dessa forma, a apresentação de cada um dos artefatos expostos nos museus não costuma ser questionada. Jacó-Vilela (2012) aponta a 
importância desse questionamento pontuando que, ao se fazer história, é necessário considerar as particularidades do lugar de onde se fala, as posições - sociais e geográficas - que o pesquisador ocupa, bem como aquilo que orienta suas escolhas metodológicas, os objetivos e os propósitos da investigação. Essa compreensão pressupõe que o historiador está completamente envolvido no processo de construção do conhecimento histórico, pois as percepções, os caminhos escolhidos e o modo de encarar a pesquisa dizem respeito a uma singularidade própria daquele que está disposto a se debruçar sobre os fatos. Isso significa que, ao se tornar um pesquisador, por mais que a cientificidade e a objetividade estejam no horizonte, os fatos são encarados a partir de uma lente própria, que engloba subjetividade, ideias e ideais daquele que pesquisa.

Organizado de maneira simples, com linguagem fácil e conteúdo acessível, o livro adota uma posição que se opõe à ideia predominante do que é fazer história, sobretudo no que diz respeito à história da Psicologia. Levando o leitor a reflexões sobre as análises e as construções históricas desse campo da ciência, o livro busca despertar o interesse pelos estudos (históricos) da Psicologia e contribuir para a formação dos pesquisadores que possuem o desejo de se aventurar nessa área, além de propiciar reflexões críticas, capazes de desconstruir as hierarquias e alienações que o modo tradicional de se fazer história pode nos impor.

Em vista disso, nos três primeiros capítulos os organizadores do livro tratam sobre as maneiras que a história da Psicologia é, comumente, construída, buscando alinhar debates entre as motivações dos estudos históricos e os efeitos que eles trazem para esse campo da ciência. Os três últimos capítulos, redigidos, respectivamente, por Fernando Larcerda Jr, Hildeberto Vieira Martins e Renato Sampaio, focalizam questões que ainda não possuem destaque nos livros de Psicologia e nas reflexões históricas da ciência psicológica: a Psicologia da Libertação, os aspectos relacionados à raça e ao racismo e, ainda, à história da Psicologia Social.

Do ponto de vista teórico-metodológico, o livro se ancora, por um lado, na Escola dos Annales, que rompe com as noções clássicas de historiografia e apresenta novas maneiras de se pensar a realidade presente, a partir da relação que ela possui com o passado (uma relação histórica); e por outro, na genealogia foucaultiana, que consiste numa crítica ao positivismo e suas neutralizações - uma crítica àquilo que está estabelecido e não é passível de mudança. Os sentidos da genealogia foucaultiana apontam para um desvendar das formas de poder que existem em uma sociedade. Sob esse olhar, o livro procura compreender o modo como algumas práticas psicológicas contribuíram para a legitimação de mecanismos de controle e o estabelecimento de um olhar individualista para 0 
sujeito, cooperando com o discurso do capitalismo e da superioridade étnica que sustenta o racismo.

A linguagem clara e a simplicidade com que temas tão complexos são abordados no livro prendem o leitor e despertam sua curiosidade, além de movimentar as paixões pessoais daqueles que se interessam pelo campo, incentivando a busca de novas leituras sobre o assunto. O olhar crítico e social do texto possibilita que o leitor interpele e problematize as questões inerentes à Psicologia, o que contribui para o amadurecimento crítico-reflexivo da ciência e de sua história.

É importante ressaltar que, por suas pretensões introdutórias, o livro apresenta alguns conceitos de maneira básica e resumida, o que significa que os possíveis aprofundamentos devem se dar a partir da leitura de outros textos complementares. A obra, porém, cumpre muito bem a função de preparar o terreno para leituras futuras, pois desperta o interesse de estudar mais sobre o assunto, além de oferecer algumas preciosas indicações de leituras que podem contribuir para os referidos aprofundamentos.

Para sustentar a argumentação geral da História Social da Psicologia, os organizadores utilizam diversos recursos didáticos, exemplos concretos e analogias com elementos cotidianos, o que torna a leitura leve e interessante. A divisão do texto em temas e subtemas e o uso de elementos da atualidade para exemplificar as reflexões teóricas facilitam a compreensão do conteúdo.

As discussões estabelecidas no livro são bastante relevantes para o cenário atual, dada a impossibilidade de pensar o sujeito descolado de sua realidade e daquilo que é construído socialmente. Apresentando críticas ao que chamamos de "fato histórico", o livro desenvolve a noção de uma fabricação histórica, que propicia a desnaturalização de aspectos sociais, uma vez que não existem fatos inflexíveis, mas sim uma constante construção e desconstrução de momentos históricos.

A obra sustenta que, em sua prática, os psicólogos devem olhar para a história, no sentido de reconhecer que os dados e conclusões da ciência psicológica são circunstanciais e não permanecem estáveis, pois sofrem modificações de acordo com a época. Além disso, também defende que devemos investigar a Psicologia na história para compreender como esse campo do saber contribuiu para a construção da sociedade em que vivemos atualmente. Sob essa perspectiva, preserva-se a ideia de que, para além de uma historicização da Psicologia, ao encararmos o devir histórico a partir de uma análise crítica, estaríamos caminhando para uma prática libertária da Psicologia, capaz de desencerrar o ser humano de diferentes formas de opressão.

Abordando aspectos autocríticos e éticos que demarcam o comprometimento do psicólogo com valores e princípios da profissão, o livro possibilita um reconhecimento das influências políticas, 
ideológicas e sociais na construção do saber psicológico - bem como da influência do saber psicológico na concepção dessas instâncias. 0 leitor, ao refletir sobre isso, pode reconhecer e pensar sobre os caminhos que a Psicologia percorre na intervenção social, capaz de promover a saúde, o bem-estar e a libertação dos sujeitos.

Para finalizar, consideramos, em consonância com as ideias dos autores, que o fundamental no fazer histórico está nos "porquês" escondidos detrás dele. Desse modo, poderíamos afirmar que "fazer história é desfazer museus" (Portugal, Facchinetti \& Castro, 2018, p. 15), no sentido de que desnaturalizar ideias fixas e contestar fatos consumados podem promover modificações nas organizações tradicionais e reificadas dos museus, contribuindo para a movimentação e a reconstrução dialética de monumentos rígidos.

\section{Referências}

Portugal, F., Facchinetti, C., \& Castro A. C. (Orgs.) (2018). História Social da Psicologia. Rio de Janeiro: Nau.

Jacó-Vilela, A. M. (2012). História da Psicologia no Brasil: uma narrativa por meio de seu ensino. Psicologia: ciência e profissão, 32(1), 28-43. doi: 10.1590/S141498932012000500004

\section{Endereço para correspondência \\ Sérgio Cirino}

Universidade Federal de Minas Gerais - UFMG

Programa de Pós-Graduação em Psicologia

Av. Presidente Antônio Carlos, 6627, Pampulha, CEP 31270-901, Belo Horizonte MG, Brasil

Endereço eletrônico: sergiocirino99@yahoo.com

\section{Deborah Christina Lopes Hoffmam}

Pontifícia Universidade Católica de Minas Gerais - PUC-MG

Faculdade de Psicologia da Puc Minas - Programa de Graduação em Psicologia

Rua do Rosário, 1081, Angola, CEP 32604-115, Betim - MG, Brasil

Endereço eletrônico: deborahhoffmam@hotmail.com

Recebido em: 19/12/2018

Reformulado em: 28/01/2019

Aceito em: 28/01/2019

\section{Notas}

* Psicólogo, Mestre e Doutor em Psicologia pela Universidade de São Paulo.

** Graduanda em Psicologia pela Pontifícia Universidade Católica de Minas Gerais.

Este artigo de revista Estudos e Pesquisas em Psicologia é licenciado sob uma Licença Creative Commons Atribuição-Não Comercial 3.0 Não Adaptada. 